\title{
PENERAPAN GSTAR-SUR PADA JUMLAH PENUMPANG PESAWAT DOMESTIK DI BANDARA INDONESIA
}

\author{
Gilang Habibie, Yundari, Hendra Perdana
}

\begin{abstract}
INTISARI
Generalized space time autoregressive (GSTAR) adalah model ruang waktu yang banyak digunakan di Indonesia. Sebagian besar penelitian model GSTAR menggunakan ordinary least square (OLS) untuk mengestimasi parameter. Namun, estimasi dengan metode OLS pada model GSTAR dengan residual saling berkorelasi akan menghasilkan estimator yang tidak efisien terutama pada data musiman. Metode estimasi yang sesuai untuk residual yang saling berkorelasi adalah generalized least square (GLS), yang biasa digunakan dalam model seemingly unrelated regression (SUR). Penelitian ini bertujuan untuk menganalisis model GSTAR-SUR dan membandingkannya dengan GSTAR-OLS dengan bobot seragam dan jarak. Data yang digunakan adalah data jumlah penumpang pesawat domestik setiap bulan di Bandara Polonia/Kualanamu, Soekarno-Hatta, Juanda dan Ngurah Rai dari Januari 2006 hingga September 2019. Hasil estimasi parameter GSTAR-SUR dengan bobot seragam adalah Polonia/Kualanamu $\left(\varnothing_{10}=-0,494\right.$; $\left.\varnothing_{11}=0,046\right)$, Soekarno-Hatta $\left(\varnothing_{10}=-0,300 ; \varnothing_{11}=-0,828\right)$, Juanda $\left(\varnothing_{10}=-0,451 ; \varnothing_{11}=0,033\right)$ dan Ngurah Rai $\left(\varnothing_{10}=-0,198 ; \varnothing_{11}=-0,019\right)$. Sedangkan GSTAR-SUR dengan bobot jarak menghasilkan estimasi Polonia/Kualanamu $\left(\varnothing_{10}=-0,492 ; \varnothing_{11}=0,026\right)$, Soekarno-Hatta $\left(\varnothing_{10}=-0,292 ; \varnothing_{11}=-1,186\right)$, Juanda $\left(\varnothing_{10}=-\right.$ 0,$\left.455 ; \varnothing_{11}=0,058\right)$ dan Ngurah Rai $\left(\varnothing_{10}=-0,211 ; \emptyset_{11}=0,017\right)$. Berdasarkan nilai MAPE GSTAR-SUR lebih baik dari GSTAR-OLS dengan nilai MAPE untuk model GSTAR-OLS adalah 12,90\% pada bobot seragam dan 13,43\% pada bobot jarak. Model GSTAR-SUR menghasilkan nilai MAPE 6,65\% untuk bobot seragam dan 7,06\% untuk bobot jarak. Model terbaik adalah GSTAR-SUR bobot seragam dengan nilai MAPE 6,65\%.
\end{abstract}

Kata Kunci : OLS, GLS, spacetime, korelasi eror

\section{PENDAHULUAN}

Generalized space time autoregressive (GSTAR) merupakan salah satu model yang digunakan untuk memodelkan dan meramalkan data yang memunyai keterkaitan waktu sebelumnya dan keterkaitan dengan lokasi yang bSerdekatan. Sampai saat ini, sebagian besar penelitian yang berkaitan dengan model GSTAR terbatas pada data spatio-temporal dan non-musiman. Metode ordinary least square (OLS) paling sering digunakan untuk mengestimasi parameter pada model GSTAR yang biasa ditulis sebagai GSTAR-OLS. Namun, estimasi parameter menggunakan metode OLS dapat menghasilkan estimator yang tidak efisien pada data yang memiliki residual saling berkolerasi. Metode estimasi untuk data yang memiliki residual yang saling berkorelasi dapat menggunakan metode generalized least square (GLS) yang biasa digunakan dalam model seemingly unrelated regression (SUR). Data penumpang pesawat adalah contoh data musiman yang sering ditemukan dalam kehidupan. Jumlah penumpang pesawat memiliki kecenderungan meningkat ketika di hari libur. Data penumpang pesawat memiliki kecenderungan pola musiman sehingga dapat dimodelkan dengan pendekatan model GSTAR-SUR dengan metode GLS untuk mengestimasi parameter model.

Data jumlah penumpang pesawat domestik yang digunakan dalam penelitian ini adalah data penumpang pesawat di empat bandara utama Indonesia yaitu Polonia/Kualanamu, Soekarno-Hatta, Juanda dan Ngurah Rai. Bandara Soekarno-Hatta merupakan kantor pusat otoritas bandar udara wilayah I, bandara Polonia/Kualanamu adalah kantor pusat wilayah II, bandara Juanda adalah kantor pusat wilayah III dan bandara Ngurah Rai adalah kantor pusat wilayah IV. Pada tanggal 25 Juli 2013, 
bandara Polonia mengalami perpindahan ke bandara Kualanamu. Data yang digunakan adalah data bulanan dari Januari 2006 sampai dengan September 2019. Data dibagi menjadi data in sample dan out sample. Data in sample dimulai dari Januari 2006 hingga Desember 2018. Sedangkan data out sample dimulai dari Januari hingga September 2019. Metode GSTAR-OLS dan GSTAR-SUR yang digunakan dibatasi dengan orde 1 dengan menggunakan pembobotan lokasi seragam dan jarak. Tujuan dari penelitian ini untuk menganalisis model dugaan GSTAR-SUR yang sesuai pada data jumlah penumpang pesawat domestik di empat bandara utama Indonesia. Selain itu, penelitian ini bertujuan untuk membandingkan model GSTAR-OLS dan GSTAR-SUR dengan bobot lokasi seragam dan jarak.

Tahapan-tahapan dalam penelitian ini, pertama data in sample diuji kestasioneran terhadap mean. Data yang tidak stasioner dilakukan differencing hingga data menjadi stasioner. Selanjutnya dilakukan penentuan bobot spasial yaitu bobot seragam dan jarak berdasarkan jarak sesungguhnya antar bandara. Selanjutnya dilakukan estimasi parameter menggunakan estimasi OLS dan SUR serta dilakukan uji signifikansi. Maka didapat empat model, yaitu GSTAR-OLS bobot seragam dan jarak serta GSTARSUR bobot seragam dan jarak. Model-model yang telah didapat selanjutnya digunakan untuk estimasi jumlah penumpang pesawat domestik. Selanjutnya, hasil estimasi data keempat model dibandingkan dan ditentukan model terbaik. Selanjutnya, dilakukan uji asumsi residual. Berikut adalah diagram alir (flowchart) dari model GSTAR untuk estimasi penumpang pesawat domestik pada empat bandara di Indonesia.

\section{KESTASIONERAN}

Stasioneritas data dibagi menjadi dua, yakni stasioner kuat dan lemah. Stasioner lemah merupakan stasioner orde 2 yang berarti harus stasioner terhadap mean dan varians. Data dikatakan stasioner jika tidak mengalami perubahan yang signifikan. Uji stasioneritas dapat dilakukan dengan uji Augmented Dickey-Fuller (ADF). Uji ADF dilakukan dengan melihat keberadaan unit root dalam model. Pengujian dilakukan dengan menguji hipotesis $H_{0}: \rho=0$ dalam persamaan regresi [1].

$$
Z(t)=a+\delta t+\rho Z(t-1)+\sum_{j=1}^{k} \phi_{j} Z(t-j)+e_{t},
$$

dengan $z(t)$ adalah variabel pengamatan pada waktu ke- $t$. $a$ adalah nilai konstanta. $\delta$ adalah nilai parameter regresi untuk trend. $\rho$ adalah nilai parameter regresi untuk lag ke-1. $\varnothing_{j}$ adalah nilai parameter regresi untuk lag ke-j. $e_{t}$ adalah nilai kesalahan pada waktu ke- $t$.

Data dikatakan stasioner apabila tidak terdapat unit root. Uji ADF dilakukan dengan menetapkan alternatif hipotesis tidak terdapat unit root atau data stasioner dengan statistik uji:

dengan:

$$
\mathrm{ADF} \text { hitung }=\frac{\hat{\phi}-1}{S E(\hat{\phi})},
$$

$$
S E(\hat{\phi})=\left[\hat{\phi}_{e}^{2}\left(\sum_{t=1}^{n} Z_{t-1}^{2}\right)\right]^{\frac{1}{2}} \operatorname{dan} \hat{\phi}_{e}^{2}=\sum_{t=1}^{n} \frac{\left(Z_{t}-\hat{\phi} Z_{t-1}\right)}{(n-1)} .
$$

Alternatif hipotesis diterima jika nilai statistik uji ADF hitung kurang dari nilai daerah kritis. Jika alternatif hipotesis diterima maka bersifat stasioner [1].

Jika data yang digunakan tidak memenuhi stasioner dalam mean maka dilakukan differencing atau pembedaan antara data pengamatan pada waktu ke- $t\left(Z_{t}\right)$ dengan data pengamatan pada waktu sebelumnya $\left(Z_{t-1}\right)$ persamaan yang digunakan adalah sebagai berikut:

$$
W_{t}=Z_{t}-Z_{t-1} \text {. }
$$




\section{GENERALIZED SPACE TIME AUTOREGRESSIVE (GSTAR)}

Jika diketahui $\{Z(t): t=0, \pm 1, \pm 2, \ldots, \pm T\}$ merupakan sebuah deret waktu dari $N$ lokasi, maka model GSTAR dari orde waktu $p$ dan orde spasial $\lambda_{1}, \lambda_{2}, \ldots, \lambda_{p}$ GSTAR $\left(p ; \lambda_{1}, \lambda_{2}, \ldots, \lambda_{p}\right)$ dalam notasi matriks dapat ditulis sebagai berikut [2]:

$$
\mathbf{Z}(t)=\sum_{k=1}^{P}\left(\boldsymbol{\Phi}_{k 0}+\sum_{l=1}^{\lambda_{p}} \boldsymbol{\Phi}_{k l} \mathbf{W}\right) \mathbf{Z}(t-k)+\mathbf{e}(t)
$$

dengan:

z(t) : vektor pengamatan pada waktu ke- $t$ lokasi ke- $n$ yang berukuran $(\mathrm{nx} 1)$

$\boldsymbol{\Phi}_{k \mathbf{0}} \quad$ : matriks diagonal dengan elemen parameter waktu pada lag ke- $k$ di lokasinya sendiri

$\Phi_{k l} \quad$ : matriks diagonal dengan elemen parameter spasial pada lag ke- $l$ dan lag waktu ke- $k$

$\mathbf{w}^{(l)} \quad$ : matriks pembobot spasial

$\mathbf{e}(t) \quad$ : galat dari model.

Data yang mengandung pola musiman dapat menggunakan model GSTAR musiman. Secara matematis, model GSTAR $\left(p ; \lambda_{1}, \lambda_{2}, \ldots, \lambda_{p}\right)^{s}$ untuk pola data musiman sebagai berikut [3]:

$$
\mathbf{Z}(t)=\sum_{k=1}^{P}\left(\boldsymbol{\Phi}_{k 0}^{s}+\sum_{l=1}^{\lambda_{p}} \boldsymbol{\Phi}_{k l}^{s} \mathbf{W}\right) \mathbf{Z}(t-s)+\mathbf{e}(t)
$$

dengan:

$\boldsymbol{\Phi}^{s}{ }_{k 0} \quad$ : matriks diagonal dengen elemen parameter waktu pada lag ke- $k$ di lokasinya sendiri dengan periode musiman $s$

$\boldsymbol{\Phi}^{s}{ }_{k l} \quad$ : matriks diagonal dengen elemen parameter spasial pada lag ke- $l$ pada lag waktu ke- $k$ dengan periode musiman $s$.

\section{PEMBOBOTAN LOKASI}

Matriks bobot lokasi dapat bersifat simetris atau tidak simetris. Matriks bobot lokasi berukuran $(\mathrm{NxN})$ dan memiliki sifat-sifat sebagai berikut [4]:

1. Bobot bersifat positif, $w_{i j}>0$.

2. Jumlah bobot untuk setiap lokasi adalah 1 .

3. $\sum_{j=1}^{N} w_{i j}=1$ untuk setiap $i \operatorname{dan} \sum_{i=1}^{N} \sum_{j=1}^{N} w_{i j}=N$.

4. Diagonal matriks bobot adalah nol, karena untuk suatu lokasi dianggap tidak ada jarak dengan dirinya sendiri.

Ada beberapa matriks bobot spasial yang digunakan dalam model GSTAR. Beberapa metode yang digunakan dalam penentuan pembobotan lokasi dalam GSTAR adalah sebagai berikut [3]:

1. Bobot seragam

Pembobotan dengan bobot seragam untuk lokasi $j$ terhadap lokasi $i$ adalah $w_{i j}=1 / n_{i}$ dengan $w_{i j}$ adalah bobot lokasi $j$ terhadap $i$ dan $n_{i}$ adalah banyak lokasi yang berpengaruh pada lokasi $i$.

2. Bobot jarak

Pembobotan dengan bobot jarak adalah jarak sebenarnya antar lokasi di lapangan. Perhitungan bobot jarak diperoleh dari jarak sebenarnya kemudian distandarisasi. 


\section{SEEMINGLY UNRELATED REGRESSION (SUR)}

SUR adalah sistem persamaan yang terdiri dari beberapa persamaan regresi dimana residualnya tidak berkolerasi antar pengamatan dalam satu persamaan, tetapi residualnya berkolerasi antar persamaan. GLS adalah penduga parameter regresi yang memerhatikan adanya korelasi dari residual antar persamaan, dimana nilai residual diperoleh dari penaksiran OLS, yang nantinya digunakan dalam perhitungan untuk menduga koefisien regresi pada sistem persamaan SUR. Secara umum model SUR untuk $N$ buah persamaan dimana masing-masing persamaan terdiri dari $K$ variabel prediktor dapat ditulis sebagai berikut [3]:

$$
\begin{aligned}
& Y_{1}=\beta_{10}+\beta_{11} X_{11}+\beta_{12} X_{12}+\ldots+\beta_{1 K} X_{1 K}+e_{1} \\
& Y_{2}=\beta_{20}+\beta_{21} X_{21}+\beta_{22} X_{22}+\ldots+\beta_{2 K} X_{2 K}+e_{2} \\
& \vdots \\
& Y_{N}=\beta_{N 0}+\beta_{N 1} X_{N 1}+\beta_{N 2} X_{N 2}+\ldots+\beta_{N K} X_{N K}+e_{N}
\end{aligned},
$$

dengan asumsi yang harus dipenuhi pada persamaan model SUR adalah sebagai berikut $E(\varepsilon)=0$ dan $E\left(\varepsilon \varepsilon^{\prime}\right)=\sigma_{i j} \mathrm{I}_{T}$ dimana $i, j=1,2, \ldots, N$.

\section{ESTIMASI PARAMETER MODEL GSTAR-SUR}

Diketahui bahwa $Z(t): t=0, \pm 1, \pm 2, \ldots, \pm T$ adalah data ruang waktu dengan $N$ lokasi dan 12 periode musiman sehingga model GSTAR yang didapatkan adalah GSTAR $(1,1)^{12}$. Model GSTAR $(1,1)^{12}$ dapat dituliskan dalam notasi matriks sebagai berikut [5]:

$$
\mathbf{Z}(\mathbf{t})=\left(\Phi_{0}^{12}+\Phi_{1}^{12} \mathbf{W}\right) \mathbf{Z}(\mathbf{t}-\mathbf{1 2})+\mathbf{e}(\mathbf{t})
$$

dengan

$\mathbf{\Phi}_{\mathbf{0}}^{\mathbf{1 2}}$ : Parameter waktu dengan periode musiman 12

$\mathbf{\Phi}_{\mathbf{1}}^{\mathbf{1 2}}$ : Parameter spasial dengan periode musiman 12.

Adapun parameter waktu dan spasial serta bobot dapat ditulis sebagai berikut:

$$
\boldsymbol{\Phi}_{\mathbf{0}}^{\mathbf{1 2}}=\left[\begin{array}{cccc}
\phi_{10}^{12} & 0 & \cdots & 0 \\
0 & \phi_{20}^{12} & \cdots & 0 \\
\vdots & \vdots & \ddots & \vdots \\
0 & 0 & \cdots & \phi_{N 0}^{12}
\end{array}\right], \boldsymbol{\Phi}_{\mathbf{1}}^{\mathbf{1 2}}=\left[\begin{array}{cccc}
\phi_{11}^{12} & 0 & \cdots & 0 \\
0 & \phi_{21}^{12} & \cdots & 0 \\
\vdots & \vdots & \ddots & \vdots \\
0 & 0 & \cdots & \phi_{N 1}^{12}
\end{array}\right], \mathbf{W}=\left[\begin{array}{cccc}
0 & w_{12} & \cdots & w_{1 N} \\
w_{21} & 0 & \cdots & w_{2 N} \\
\vdots & \vdots & \ddots & \vdots \\
w_{N 1} & w_{N 2} & \cdots & 0
\end{array}\right]
$$

Sehingga didapatkan dalam model persamaan matematis dalam bentuk matriks adalah sebagai berikut:

$$
\left[\begin{array}{c}
Z_{1}(t) \\
Z_{2}(t) \\
\vdots \\
Z_{N}(t)
\end{array}\right]=\left[\begin{array}{ccccc}
Z_{1}(t-12) & V_{1}(t-12) & \cdots & 0 & 0 \\
0 & 0 & \cdots & 0 & 0 \\
0 & 0 & \cdots & 0 & 0 \\
\vdots & \vdots & \ddots & 0 & 0 \\
0 & 0 & \cdots & Z_{N}{ }^{(t-12)} & V_{N}{ }^{(t-12)}
\end{array}\right]
$$

Dalam hal ini, masing-masing notasi matriks dapat diuraikan sebagai berikut: 


$$
\mathbf{Z}_{\mathbf{i}}(t)=\left[\begin{array}{c}
z_{i}(1) \\
z_{i}(2) \\
\vdots \\
z_{i}(T)
\end{array}\right], \mathbf{Z}_{\mathbf{i}}(t-12)=\left[\begin{array}{c}
z_{i}(-11) \\
z_{i}(-10) \\
\vdots \\
z_{i}(T-12)
\end{array}\right], \mathbf{e}_{\mathbf{i}}(t)=\left[\begin{array}{c}
e_{i}(1) \\
e_{i}(2) \\
\vdots \\
e_{i}(T)
\end{array}\right], \mathbf{V}_{\mathbf{i}}(t-12)=\left[\begin{array}{c}
v_{i}(-11) \\
v_{i}(-10) \\
\vdots \\
v_{i}(T-12)
\end{array}\right]=\left[\begin{array}{c}
\sum_{j \neq i} w_{i j} z_{j}(-11) \\
\sum_{j \neq i} w_{i j} z_{j}(-10) \\
\vdots \\
\sum_{j \neq i} w_{i j} z_{j}(T-12)
\end{array}\right],
$$

dengan $i=1,2, \ldots, N$. Untuk setiap lokasi $i$, diperoleh persamaan seperti berikut ini,

$$
Z_{i}(t)=\phi_{i 0}^{12} Z_{i}(t-12)+\phi_{i 1}^{12} V_{i}(t-12)+e_{i}(t)
$$

Persamaan model GSTAR-SUR dapat ditulis dalam bentuk seperti berikut,

$$
\mathrm{Y}_{i, t}=X_{i, t} \beta_{i}+\varepsilon_{i, t} \text {. }
$$

dengan:

$$
\mathbf{Y}_{\mathbf{i}, \mathbf{t}}=\mathbf{Z}_{\mathbf{i}}(t), \mathbf{X}_{\mathbf{i}, \mathbf{t}}=\left[\begin{array}{ll}
\mathbf{Z}_{\mathbf{i}}(t-12) & \mathbf{V}_{\mathbf{i}}(t-12)
\end{array}\right], \boldsymbol{\beta}_{\mathbf{i}}=\left[\begin{array}{c}
\phi_{i 0}^{12} \\
\phi_{i 1}^{12}
\end{array}\right], \boldsymbol{\varepsilon}_{i, t}=\mathbf{e}_{i}(t) .
$$

Sehingga diperoleh persamaan model GSTAR-SUR dalam bentuk matriks seperti berikut ini,

$$
\begin{aligned}
& {\left[\begin{array}{c}
Y_{1, t} \\
Y_{2, t} \\
\vdots \\
Y_{N, t}
\end{array}\right]=\left[\begin{array}{cccc}
X_{1, t} & 0 & \cdots & 0 \\
0 & X_{2, t} & \cdots & 0 \\
\vdots & \vdots & \ddots & \vdots \\
0 & 0 & \cdots & X_{N, t}
\end{array}\right]\left[\begin{array}{c}
\beta_{1} \\
\beta_{2} \\
\vdots \\
\beta_{N}
\end{array}\right]+\left[\begin{array}{c}
\varepsilon_{1, t} \\
\varepsilon_{2, t} \\
\vdots \\
\varepsilon_{N, t}
\end{array}\right]} \\
& \mathbf{Y}=\mathbf{X} \quad \boldsymbol{\beta}+\boldsymbol{\varepsilon}
\end{aligned}
$$

Pada model GSTAR-SUR diasumsikan residual tidak berkolerasi di setiap lokasi ke- $i$,

$$
E\left(\varepsilon_{i, t} \varepsilon_{j, s}\right)=\left\{\begin{array}{l}
0, t \neq s \\
\sigma_{i j}, t=s
\end{array},\right.
$$

dengan $i, j=1,2, \ldots, N$; dan $t, s=1,2, \ldots, T$.

Residual pada model GSTAR-SUR adalah berkolerasi antar persamaan atau lokasi, sehingga matriks varians-kovarians adalah

$$
E\left(\varepsilon \varepsilon^{\prime}\right)=\boldsymbol{\sigma}_{i j} \mathbf{I}_{T},
$$

karena $E\left(\varepsilon \varepsilon^{\prime}\right)=\boldsymbol{\sigma}_{i j} \mathbf{I}_{T}$ maka:

$$
E\left(\varepsilon \varepsilon^{\prime}\right)=\left[\begin{array}{cccc}
\sigma_{11} & \sigma_{12} & \cdots & \sigma_{1 N} \\
\sigma_{21} & \sigma_{22} & \cdots & \sigma_{2 N} \\
\vdots & \vdots & \ddots & \vdots \\
\sigma_{N 1} & \sigma_{2 N} & \cdots & \sigma_{N N}
\end{array}\right] \otimes \mathbf{I}_{\mathbf{T}}=\mathbf{\Sigma} \otimes \mathbf{I}_{\mathbf{T}}=\boldsymbol{\Omega} .
$$

Dengan $\boldsymbol{\Omega}$ adalah matriks berukuran $(\mathrm{N} \times \mathrm{T}) \times(\mathrm{N} \times \mathrm{T})$. Penaksiran parameter dalam model GSTAR-SUR adalah menggunakan GLS. Metode GLS diperoleh dengan meminimumkan generalized sum of square $\boldsymbol{\varepsilon}^{\prime} \mathbf{\Omega}^{-1} \boldsymbol{\varepsilon}$. Hasil estimasi parameter model GSTAR-SUR musiman adalah sebagai berikut:

$$
\hat{\boldsymbol{\beta}}=\left(\mathbf{X}^{\prime} \mathbf{\Omega}^{-1} \mathbf{X}\right)^{-1} \mathbf{X}^{\prime} \mathbf{\Omega}^{-1} \mathbf{Y},
$$

Karena $\boldsymbol{\Omega}=\boldsymbol{\Sigma} \otimes \mathbf{I}_{\mathrm{T}}$, maka estimator $\boldsymbol{\beta}$ adalah:

$$
\hat{\boldsymbol{\beta}}=\left(\mathbf{X}^{\prime}\left(\boldsymbol{\Sigma} \otimes \mathbf{I}_{\mathrm{T}}\right)^{-1} \mathbf{X}\right)^{-1} \mathbf{X}^{\prime}\left(\boldsymbol{\Sigma} \otimes \mathbf{I}_{\mathrm{T}}\right)^{-1} \mathbf{Y} .
$$


Tabel 1. Statistik deskriptif data in sample

\begin{tabular}{lrrrr}
\hline & Polonia/Kualanamu & Soekarno-Hatta & Juanda & Ngurah Rai \\
\hline Mean & 237.561 & 1.449 .742 & 498.040 & 295.585 \\
Minimum & 125.256 & 635.230 & 221.823 & 107.825 \\
Maximum & 384.004 & 2.132 .360 & 889.548 & 547.576 \\
Standard Deviation & 60.136 & 359.904 & 154.591 & 112.260 \\
Count & 156 & 156 & 156 & 156 \\
\hline
\end{tabular}

\section{MEAN ABSOLUTE PERCENTAGE ERROR (MAPE)}

MAPE adalah persentase rata-rata kesalahan mutlak pada setiap periode waktu. MAPE dirumuskan sebagai berikut:

$$
\text { MAPE }=\frac{\sum_{t=1}^{n}\left|\frac{Z_{t}-\hat{Z} t}{Z_{t}}\right|}{n} \times 100 \%,
$$

dengan $z_{t}$ adalah data aktual pada periode ke- $t, \hat{z}_{t}$ adalah data estimasi pada periode ke- $t$ dan $n$ adalah banyak datum. Suatu model dikatakan memiliki kinerja sangat baik jika nilai MAPE di bawah $10 \%$ dan dikatakan memiliki kinerja baik jika nilai MAPE di antara 10\% dan 20\% [1].

\section{STUDI KASUS}

Data yang digunakan dalam penelitian ini merupakan data sekunder yang didapat dari Badan Pusat Statistik Nasional. Data ini menyajikan jumlah penumpang pesawat domestik setiap bulannya dari Januari 2006 hingga September 2019 di empat bandara Indonesia, yaitu Soekarno-Hatta, Polonia/Kualanamu, Juanda dan Ngurah Rai. Empat bandara utama di Indonesia tersebut merupakan kantor pusat otoritas bandar udara wilayah I hingga wilayah IV. Pada 25 Juli 2013, bandara Polonia mengalami perpindahan ke bandara Kualanamu. Banyak data yang digunakan dalam penelitian ini sebanyak 165 data yang terdiri dari 156 data in sample dan sembilan data out sample. Hasil statistik deskriptif dari data in sample jumlah penumpang pesawat domestik di empat bandara dengan periode yang digunakan Januari 2006 hingga Desember 2018 dapat dilihat pada Tabel 1.

\section{UJI KESTASIONERAN}

Data jumlah penumpang pesawat domestik dilihat kestasioneran dengan uji ADF. Berdasarkan Tabel 2 didapatkan bahwa data keempat bandara tidak stasioner sehingga data perlu dilakukan differencing. Data differencing selanjutnya diuji kestasioneranya kembali dengan uji ADF. Berdasarkan Tabel 3 data keempat bandara telah stasioner sehingga dapat dilakukan pemodelan.

Tabel 2. Hasil uji ADF

\begin{tabular}{lrrr}
\hline Lokasi & P value & Keterangan & Kestasioneran \\
\hline Polonia/Kualanamu & 0,6583 & Terima $H_{0}$ & Tidak Stasioner \\
Soekarno-Hatta & 0,4611 & Terima $H_{0}$ & Tidak Stasioner \\
Juanda & 0,2758 & Terima $H_{0}$ & Tidak Stasioner \\
Ngurah Rai & 0,1000 & Terima $H_{0}$ & Tidak Stasioner
\end{tabular}

Tabel 3. Hasil uji ADF data differencing

\begin{tabular}{lrrr}
\hline Lokasi & P value & Keterangan & Kestasioneran \\
\hline Polonia/Kualanamu & 0,01 & Tolak $H_{0}$ & Stasioner \\
Soekarno-Hatta & 0,01 & Tolak $H_{0}$ & Stasioner \\
Juanda & 0,01 & Tolak $H_{0}$ & Stasioner \\
Ngurah Rai & 0,01 & Tolak $H_{0}$ & Stasioner \\
\hline
\end{tabular}


Tabel 4. Jarak antar bandara $(\mathrm{km})$

\begin{tabular}{lrrrr}
\hline Bandara & Polonia/Kualanamu & Soekarno-Hatta & Juanda & Ngurah Rai \\
\hline Polonia/Kualanamu & 0 & 1418 & 2110 & 2412 \\
Soekarno-Hatta & 1418 & 0 & 692 & 995 \\
Juanda & 2110 & 692 & 0 & 303 \\
Ngurah Rai & 2412 & 995 & 303 & 0 \\
\hline
\end{tabular}

\section{PENENTUAN BOBOT SPASIAL}

Hasil perhitungan bobot seragam adalah sebagai berikut:

$$
\mathbf{W}=\left[\begin{array}{cccc}
0 & \frac{1}{3} & \frac{1}{3} & \frac{1}{3} \\
\frac{1}{3} & 0 & \frac{1}{3} & \frac{1}{3} \\
\frac{1}{3} & \frac{1}{3} & 0 & \frac{1}{3} \\
\frac{1}{3} & \frac{1}{3} & \frac{1}{3} & 0
\end{array}\right]
$$

Selanjutnya, ditentukan matriks bobot jarak. Penentuan bobot jarak menggunakan jarak sebenarnya antar keempat bandara pada Tabel 4 yang distandarisasi maka bobot jarak adalah sebagai berikut:

$$
\mathbf{W}=\left[\begin{array}{cccc}
0 & 0,24 & 0,36 & 0,40 \\
0,46 & 0 & 0,22 & 0,32 \\
0,68 & 0,22 & 0 & 0,10 \\
0,65 & 0,27 & 0,08 & 0
\end{array}\right]
$$

\section{ESTIMASI PARAMETER GSTAR-OLS DAN GSTAR-SUR}

Data yang telah stasioner digunakan untuk mencari parameter GSTAR. Proses perhitungan dibantu aplikasi R. Adapun hasil estimasi parameter untuk data differencing dapat dilihat pada Tabel 5.

Tabel 5. Perbandingan hasil estimasi parameter GSTAR-OLS dan GSTAR-SUR

\begin{tabular}{cccccc}
\hline \multirow{2}{*}{ Bandara } & \multirow{2}{*}{ Parameter } & \multicolumn{2}{c}{ GSTAR-OLS } & \multicolumn{2}{c}{ GSTAR-SUR } \\
\cline { 3 - 6 } & $\phi_{10}$ & $-0,188$ & $-0,177$ & $-0,494$ & $-0,492$ \\
& $\phi_{11}$ & 0,084 & 0,047 & 0,046 & 0,026 \\
Polonia/Kualanamu & $\phi_{10}$ & 0,421 & 0,426 & $-0,300$ & $-0,292$ \\
& $\phi_{11}$ & $-2,112$ & $-2,997$ & $-0,828$ & $-1,186$ \\
Soekarno-Hatta & $\phi_{10}$ & $-0,144$ & $-0,163$ & $-0,451$ & $-0,455$ \\
& $\phi_{11}$ & 0,204 & 0,348 & 0,033 & 0,058 \\
Juanda & $\phi_{10}$ & $-0,031$ & $-0,043$ & $-0,198$ & $-0,211$ \\
& $\phi_{11}$ & 0,150 & 0,202 & $-0,019$ & $-0,017$ \\
\hline \multirow{2}{*}{ Ngurah Rai } & & & & & Sobot \\
& & &
\end{tabular}


Berdasarkan Tabel 5, dari keempat model memiliki parameter yang tidak signifikan pada Bandara Soekarno-Hatta dengan nilai penjumlahan atau pengurangan parameter waktu dan lokasi lebih dari satu. Hal ini menunjukan parameter pada lokasi bandara Soekarno-Hatta tidak memenuhi syarat stasioner model GSTAR.

\section{PERBANDINGAN GTAR-OLS DAN GSTAR-SUR}

Berdasarkan Gambar 1, perbandingan data aktual dan estimasi pada out sample keempat model berpola bersesuaian dengan data aktual di keempat bandara. Namun, ada pada beberapa bulan tertentu, data estimasi keempat model memiliki selisih yang cukup jauh dengan data aktual. Secara visual hal ini menunjukan keempat model baik.

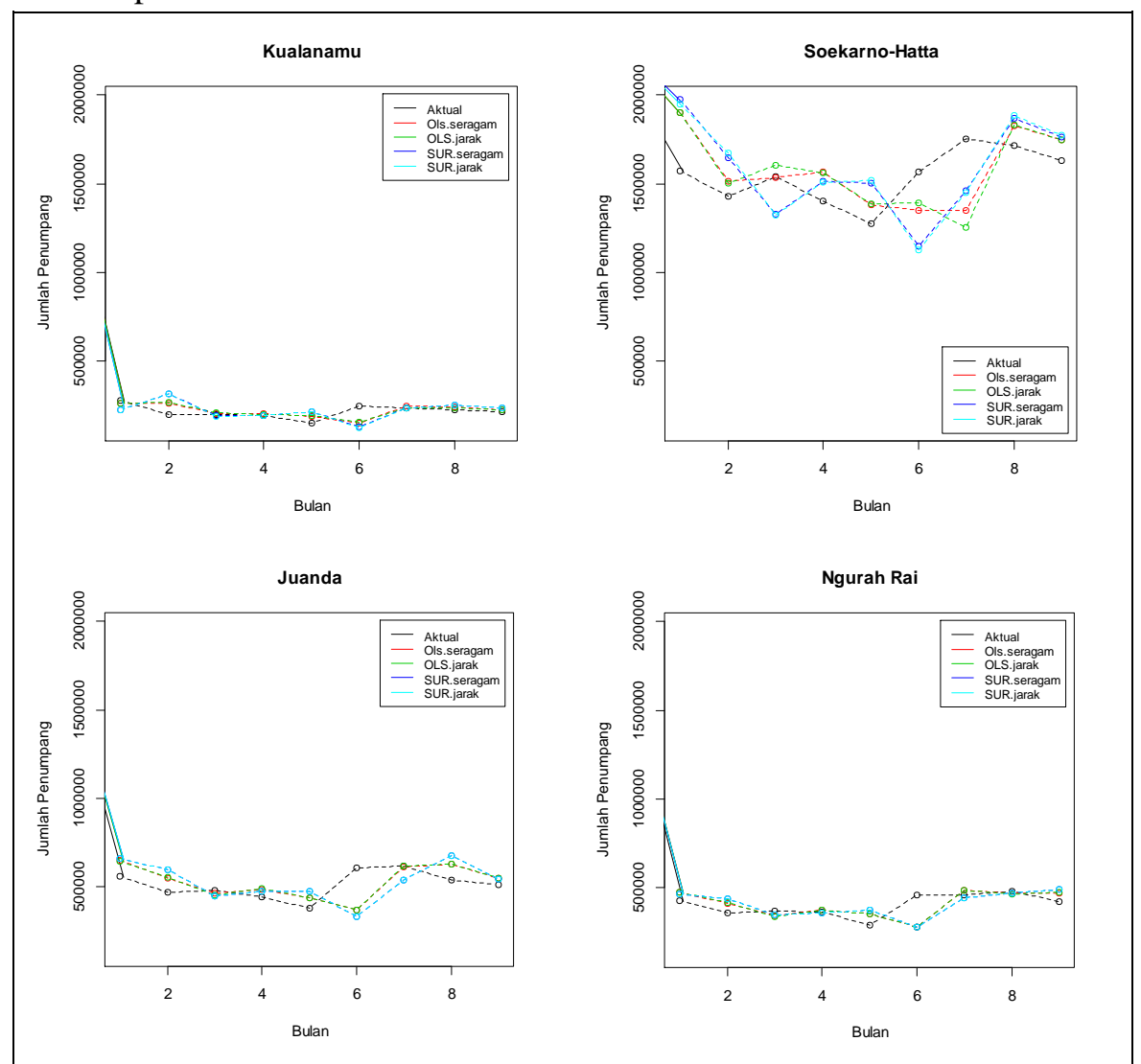

Gambar 1. Perbandingan estimasi out sample dan data aktual pada empat bandara

Tabel 6. Perbandingan MAPE out sample untuk setiap model

\begin{tabular}{lccccc}
\hline \multirow{2}{*}{ Model } & \multicolumn{5}{c}{ MAPE Out Sample } \\
\cline { 2 - 6 } & $\begin{array}{c}\text { Polonia/ } \\
\text { Kualanamu }\end{array}$ & $\begin{array}{c}\text { Soekarno- } \\
\text { Hatta }\end{array}$ & Juanda & Ngurah Rai & Total \\
\hline GSTAR-OLS & & & & & \\
Bobot Seragam & $13,71 \%$ & $10,87 \%$ & $13,83 \%$ & $13,19 \%$ & $12,90 \%$ \\
$\begin{array}{l}\text { Bobot Jarak } \\
\text { GSTAR-SUR }\end{array}$ & $13,80 \%$ & $11,63 \%$ & $14,00 \%$ & $13,43 \%$ & $13,43 \%$ \\
$\begin{array}{l}\text { Bobot Seragam } \\
\text { Bobot Jarak }\end{array}$ & $9,47 \%$ & $7,25 \%$ & $6,23 \%$ & $3,59 \%$ & $\mathbf{6 , 6 5 \%}$ \\
\hline
\end{tabular}


Berdasarkan Tabel 6, nilai MAPE pada out sample untuk model GSTAR-OLS adalah untuk bobot seragam $12,90 \%$ dan untuk bobot jarak 13,43\% dengan keduanya dikategorikan baik. Sedangkan nilai MAPE untuk model GSTAR-SUR adalah untuk bobot seragam 6,65\% dan untuk bobot jarak 7,06\% dengan keduanya dikategorikan sangat baik. Model dengan MAPE total terbaik adalah GSTAR-SUR bobot seragam dengan nilai MAPE 6,65\%.

\section{UJI ASUMSI RESIDUAL}

Berdasarkan Gambar 2, residual dari bandara Polonia/Kualanamu, Juanda dan Ngurah Rai tidak berdistribusi normal karena residual tidak berada di sekitar $Q-Q$ line hanya residual dari bandara Soekarno-Hatta yang berdistribusi normal. Hal ini menunjukan model kurang baik dalam mengestimasi data. Residual yang tidak berdistribusi normal diduga disebabkan ada estimasi parameter yang tidak signifikan. Selain itu, berdasarkan Gambar 3 dapat dilihat residual dari bandara Polonia/Kualanamu, Juanda dan Ngurah Rai tidak berdistribusi acak dengan mengelompok di daerah tertentu menunjukan eror saling berkolerasi.
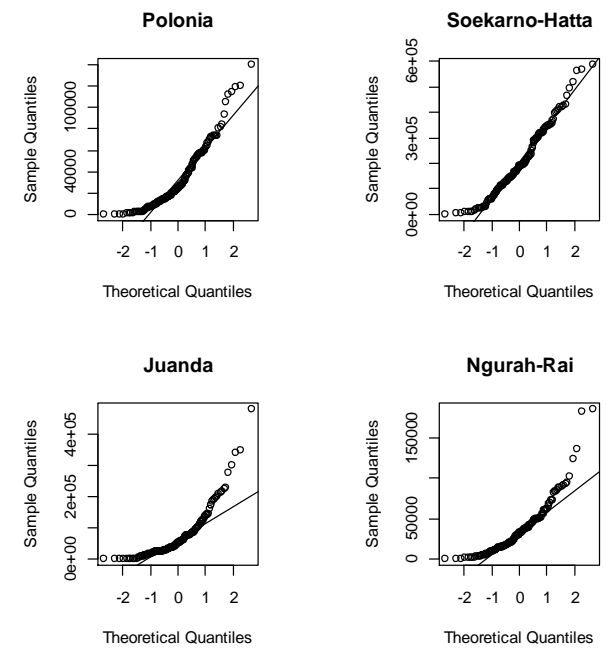

Gambar 2. $Q-Q$ plot residual model GSTAR-SUR bobot seragam

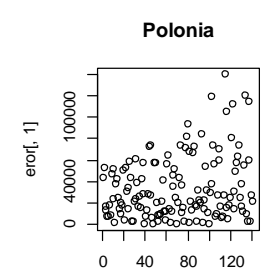

Index

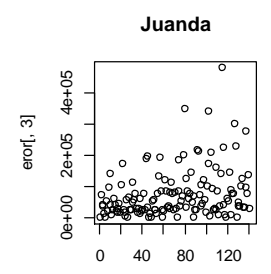

Index

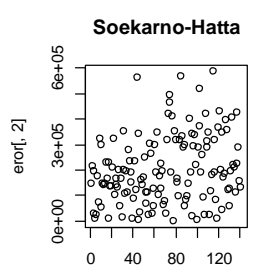

Index

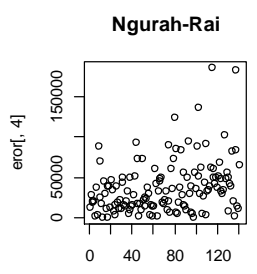

Index

Gambar 3. Scatterplot residual model GSTAR-SUR bobot seragam 


\section{PENUTUP}

Berdasarkan studi kasus menggunakan data jumlah penumpang pesawat domestik di Bandara Polonia/Kualanamu, Soekarno-Hatta, Juanda dan Ngurah Rai maka dapat disimpulkan bahwa:

1. Hasil estimasi parameter GSTAR-SUR dengan bobot seragam adalah Polonia/Kualanamu $\left(\varnothing_{10}=-\right.$ 0,$\left.494 ; \varnothing_{11}=0,046\right)$, Soekarno-Hatta $\left(\varnothing_{10}=-0,300 ; \varnothing_{11}=-0,828\right)$, Juanda $\left(\varnothing_{10}=-0,451 ; \varnothing_{11}=0,033\right)$ dan Ngurah Rai $\left(\varnothing_{10}=-0,198 ; \varnothing_{11}=-0,019\right)$. Sedangkan GSTAR-SUR dengan bobot jarak menghasilkan estimasi Polonia/Kualanamu $\left(\varnothing_{10}=-0,492 ; \varnothing_{11}=0,026\right)$, Soekarno-Hatta $\left(\varnothing_{10}=-0,292 ; \emptyset_{11}=-1,186\right)$, Juanda $\left(\varnothing_{10}=-0,455 ; \emptyset_{11}=0,058\right)$ dan Ngurah Rai $\left(\varnothing_{10}=-0,211 ; \emptyset_{11}=0,017\right)$.

2. Berdasarkan nilai MAPE GSTAR-SUR lebih baik dari GSTAR-OLS dengan nilai MAPE untuk model GSTAR-OLS adalah 12,90\% pada bobot seragam dan 13,43\% pada bobot jarak. Model GSTAR-SUR menghasilkan nilai MAPE 6,65\% untuk bobot seragam dan 7,06\% untuk bobot jarak. Model terbaik adalah GSTAR-SUR bobot seragam dengan nilai MAPE 6,65\%. Namun, residual dari estimasi data pada model GSTAR-SUR bobot seragam tidak berdistribusi normal dan tidak berdistribusi dengan acak pada bandara Polonia/Kualanamu, Juanda dan Ngurah Rai.

\section{DAFTAR PUSTAKA}

[1] Adam, I., Kusnandar, D., dan Perdana, H. Penerapan Model GSTAR $(1,1)$ untuk Data Curah Hujan. Bimaster: Buletin Ilmiah Math. Stat. dan Terapannya. 2017; 6(3):159 - 166.

[2] Borovkova, S., Lopuhaä, H. P., dan Rucjhana, B.N. Consistency and Asymptotic Normality of Least Square Estimators in Generalized STAR Models. Statistica Neerlandica. 2008; 62(4): 482-508.

[3] Prastuti, M. dan Iis, D. R. Kajian Simulasi Estimasi Parameter Model GSTAR-GLS untuk Data Berpola Musiman. Media Bina Ilmiah. 2019; 13(12):1769-1775.

[4] Suryamah, E., Ruchjana, B., N., dan Joebaedi, K. Kajian Matriks Bobot Lokasi Model Space Time Autoregresi (STAR). Jurnal Matematika Integratif.. 2013; 9(2):119-130.

[5] Setiawan, Prastuti, M dan Suhartono. S-GSTAR-SUR Model for Seasonal Spatio Temporal Data Forecasting. Malaysian Journal of Mathematical Sciences. 2016; 10: 53-65.

GILANG HABIBIE

YUNDARI

HENDRA PERDANA
: Jurusan Matematika FMIPA UNTAN, Pontianak gilang.habibie@student.untan.ac.id : Jurusan Matematika FMIPA UNTAN, Pontianak yundari@math.untan.ac.id : Jurusan Matematika FMIPA UNTAN, Pontianak hendra.perdana@math.untan.ac.id 